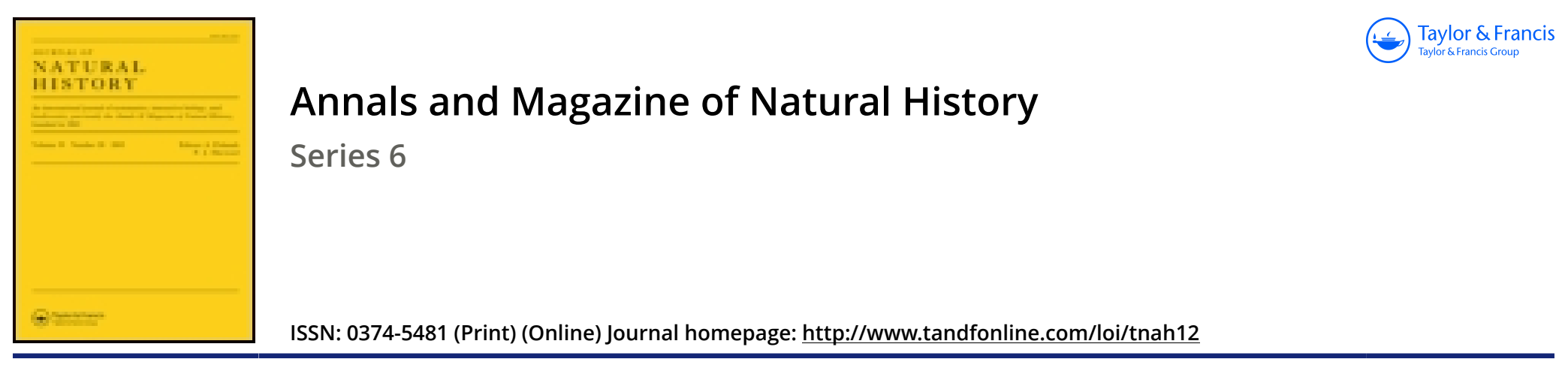

\title{
XXXII.-Description of a second species of the carnivorous genus Nandinia, from Southern Nyassaland
}

\section{Oldfield Thomas}

To cite this article: Oldfield Thomas (1893) XXXII._Description of a second species of the carnivorous genus Nandinia, from Southern Nyassaland , Annals and Magazine of Natural History, 12:69, 205-205, DOI: 10.1080/00222939308677604

To link to this article: http://dx.doi.org/10.1080/00222939308677604

曲 Published online: 06 Oct 2009.

Submit your article to this journal $\pi$

Џll Article views: 4

Q View related articles $₫$

Citing articles: 1 View citing articles 
XXXII.-Description of a Second Species of the Carnivorous Genus Nandinia, from Southern Nyassaland. By OLdFIELD Thomas.

IN connexion with the working out of the fine series of Nyassa Mammals now being sent to the National Museum by Mr. H. H. Johnston, occasion has arisen for the examination of a couple of specimens of Nandinia from the same region, collected on the river Shire by Sir John Kirk when with the Livingstone Expedition of 1863. The two specimens are flat skins of adult and young, and a comparison of them with the West-African $N$. binotata shows that they are, as might be expected from their locality, quite different specifically from that animal.

The species may be briefly diagnosed as follows:-

\section{Nandinia Gerrardi, sp. n.}

Similar to N. binotata in size and general colour, but the three prominent black lines on the dorsal aspect of the neck in that animal are entirely absent, the body is more sparsely and finely spotted, and the transverse black markings on the tail are narrower, closer together, and more sharply defined. The tail, also, of the type is considerably shorter than in $N$. binotata, but may be imperfect, so that no stress can be laid on this character. Back of ears concolorous with rest of head. Yellowish spots on withers present, but indistinct. 9.1.

Hab. Lower Shiré River, Nyassaland. Type B. M. 64. 1.

Sir John (or, as he then was, Dr.) Kirk has labelled the type specimen as follows :-

"Skin of 'Nthoro'-an animal eating mice, poultry, \&c., and living in the Lower Shiré Valley. June 1861."

It is with great pleasure that I have applied to this very distinct animal the name of my old friend $\mathrm{Mr}$. Edward Gerrard, long the right-hand man of Dr. Gray, whose services in the Museum now extend over more than 50 years, and to whose kindness and intimate knowledge of the Museum Collection of Mammals every worker in that collection, and most of all I myself, have been so largely and constantly indebted.

The discovery of second species to previously monotypic genera is always a matter of interest, while the extreme rarity of new species of Carnivora lends additional importance to the recognition of so striking a species as Nandinia Gerrardi. 